\title{
The ostensible tension between competition and cooperation in ports: a case study on intra-port competition and inter-organizational relations in the Rotterdam container handling sector
}

\author{
R. B. Castelein ${ }^{1,3^{*}}$ (D, H. Geerlings ${ }^{1,3}$ and J. H. R. Van Duin ${ }^{2,3,4}$
}

\author{
* Correspondence: castelein@essb. \\ eur.nl \\ 'Department of Public \\ Administration, Erasmus University \\ Rotterdam, Burgemeester Oudlaan \\ 50, 3062PA Rotterdam, The \\ Netherlands \\ ${ }^{3}$ Project EURECA (Effective Use of \\ Reefer Containers Through the Port \\ of Rotterdam - a transition oriented \\ approach), Netherlands \\ Organization for Scientific Research \\ (NWO), the Hague, The Netherlands \\ Full list of author information is \\ available at the end of the article
}

\begin{abstract}
Strategic alliances in the container shipping sector, and requirements imposed by consolidated hinterland modalities such as trains and barges, have resulted in container terminals facing increasing pressures to cooperate to handle increasingly intertwined container flows. However, concession agreements and market conditions often also pressure terminals to compete. This paper aims to help understand how pressures for competition and cooperation conflict, what problems this causes, what drives these tensions, and how these can be resolved.

The drivers of port competitiveness are generally conceptualized as straightforward criteria related to costs, efficiency, location, and infrastructure. Because of the focus on these 'hard', quantifiable factors, the qualitative relational underpinnings of port performance are often overlooked. This paper explores how inter-organizational relations function as a major underpinning of port performance and competitiveness. Interviews with a representative selection of stakeholders in the Port of Rotterdam reveal the problems that can occur when cooperation between terminals is under pressure. These problems relate to deficiencies in inter-organizational relationships, which do not tend to arise spontaneously in a competitive context. This paper provides a framework that helps understand how firms can simultaneously balance pressures for competition and imperatives for cross-firm integration and cooperation. Several technical and organizational solutions are suggested, but effective implementation depends on various tacit factors - including trust, shared values, and a sense of community - that determine stakeholders' willingness to commit and cooperate.
\end{abstract}

Keywords: Ports, Port governance, Container terminals, Container transport, Interorganizational relations, Intra-port competition

\section{Introduction}

In Western Europe there is traditionally strong competition between several major neighboring ports, in particular Antwerp, Rotterdam, and the German ports Hamburg and Bremerhaven. This competition is generally recognized, but within container ports themselves, there are also competitive dynamics that may in turn affect port performance and competitiveness.

(c) The Author(s). 2019 Open Access This article is distributed under the terms of the Creative Commons Attribution 4.0 International License (http://creativecommons.org/licenses/by/4.0/), which permits unrestricted use, distribution, and reproduction in any medium, provided you give appropriate credit to the original author(s) and the source, provide a link to the Creative Commons license, and indicate if changes were made. 
Container port competitiveness is generally conceptualized as driven by straightforward criteria, such as port costs, handling efficiency, hinterland connectivity, and the quality of infrastructure and services (Parola et al. 2017). The more efficient and cost-effective a port's operations are, the better should be its competitive position. The authors argue, however, that these 'hard', quantifiable factors cannot be seen in isolation from the more tacit and qualitative relational underpinnings of the way a port functions. On a deeper level, port performance itself - as evidenced by conventional measures such as efficiency and throughput growth - critically depends on the way in which port actors relate and interact in the logistics processes taking place within a port.

Competition in the container shipping sector can be distinguished at the intraport level (e.g. between actors within one port competing for the same cargo) and at the inter-port level (e.g. between different ports serving the same supply chains and/or hinterland) (Verhoeff 1981; Haezendonck 2001; Wang and Zhang 2018). So far, inter-port competition - between different ports competing for users' business - has received the most attention in the maritime and port economics literature (e.g. De Langen and Pallis 2010; Figueiredo de Oliveira and Cariou 2015; Van Hassel et al. 2016; Lagoudis et al. 2017; Castelein et al. 2019). Intra-port competition - and more broadly inter-organizational behavior within ports (including competition, as well as cooperation and other configurations of interaction and mutual dependence) have received relatively little attention, with some exceptions that do address the complexities in relations between port actors (De Langen and Pallis 2006; Van der Horst and De Langen 2008; Hall and Jacobs 2010; Verhoeven 2010; De Martino et al. 2013; Jaffee 2017). In addressing intra-port inter-organizational relationships however, authors predominantly focus on the formal aspects of port policy and governance (i.e. the position of Port Authorities and its relations with port users, such as concession agreements) and deliberate stakeholder management strategies of port authorities (Parola et al. 2018). Other studies have focused on the more tacit dimensions of inter-organizational relations, but often between firms that are not necessarily direct competitors (i.e. either vertically linked in the same logistics chain or operating in different chains) (Van der Horst and De Langen 2008; De Martino et al. 2013, 2015; Jaffee 2017). Of particular interest is the tension that arises when direct competitors also face pressures to cooperate. Recently, Clott et al. (2018) considered horizontal coordination within the liner shipping sector, and a series of recent papers explored the relatively new idea of cooperation between competing seaports from various perspectives (see Notteboom et al. (2018) for an overview). However, while the ostensible balancing act between competition and cooperation has been researched for the liner shipping sector and seaports, these dynamics at the intra-port level are of considerable practical and academic interest as well, considering the often fierce competition between neighboring terminals in contrast with their shared interest in the overall performance of the port's logistics functions. So far the tension between competitive and cooperative relationships between directly competing neighboring container terminals has not been researched yet. This study aims to explore this missing perspective by analyzing horizontal coordination and cooperation between competing container terminals in a seaport, based on a case study on the Port of Rotterdam. 
To function effectively as a transportation hub, ports should seamlessly integrate various logistics chains and processes that pass through the port. This integration may have to take place between processes of competing port users. Therefore, in contrast to competition between port actors, earlier work has shown that there is considerable pressure on firms in ports to engage in coordination and cooperation to ensure the overall efficiency of port-oriented supply chains (Van der Horst and De Langen 2008). Apart from cooperation to align and coordinate logistics processes, also innovation processes in port clusters depend on the degree to which (sometimes competing) organizations interact and cooperate (Acciaro et al. 2018). The authors researching these issues conclude that cooperation often does not arise spontaneously, and that the link between competition and cooperation within ports deserves further scrutiny. This paper further engages with this challenging question, and focuses on competitive dynamics and inter-organizational relations within container ports to explore the challenges that may arise when terminal operators compete directly, but also face pressures to cooperate.

The questions that need to be answered in this context are: What tensions may arise when port actors have to balance the pressures for competition and cooperation? Secondly, what factors drive this tension? And lastly, how may this tension be resolved?

These questions are addressed using insights from the fields of marketing, business management, and supply chain management on how barriers to, and facilitators of, supply chain integration work and can be managed. This is linked to the issue of how firms can simultaneously manage cooperation and competition. These insights are applied to the case of the Port of Rotterdam, where the importance of balancing competition and cooperation and inter-organizational relationships has recently become particularly relevant. In 2013, the terminals at the newly created Tweede Maasvlakte port extension became operational, with the Port Authority paying special attention to the competitive environment in their concession agreement policy as well as sustainability concerns (De Langen et al. 2012; Notteboom and Lam 2018). In the context of a declining freight market and overcapacity in the container-handling sector, relations between terminals, and between terminals and the Port Authority, became strained. One operator (Hutchison Ports ECT Rotterdam) even claimed $€ 1$.3bln from the Port Authority in damage compensation for the perceived unfairness with which the Port Authority granted concessions to new operators competing with the incumbent ECT (Mackor 2014). Furthermore, hold-up and congestion at and between terminals in the port of Rotterdam worsened, partly due to lack of inter-terminal coordination and cooperation (Pieffers 2017). This example shows that when relations between terminals become competitive to the extent that cooperation suffers, this has a direct negative impact on port performance. When these issues persist for longer periods of time, long-term port competitiveness suffers as well. For managers and policymakers, this study offers deeper insights into the drivers of such problems, and possible directions for solutions.

Drawing on publicly available information, information from industry publications, and interviews with decision makers from several different types of key stakeholder organizations in the Rotterdam container transport sector, this paper illustrates how the abstract notions of inter-organizational relations and supply chain integration apply to the situation within a container port. Based on this case 
study, this article considers a) the problems that can arise when cooperation and coordination fall short, b) the relational and institutional underpinnings of these dynamics, and c) possible solutions.

In addressing these questions, the study contributes to practice as well as academic discussions on several relevant issues. The relevance of the paper is that it outlines how a port's performance on important criteria - transit time, reliability and intermodal connectivity - is jeopardized when terminals fail to effectively coordinate their activities on the seaside as well as the landside. Tracing the institutional drivers of these coordination problems, the authors highlight the importance of inter-organizational relations between supply chain actors (even competitors) for effective supply chain coordination and ultimately port performance. This leads to recommendations for managers and policymakers, based on technical and organizational solutions discussed in literature. To academic research, the study contributes a missing perspective on coordination within seaports. Earlier research in this area focused predominantly on vertical coordination in container ports (notably Van Der Horst and De Langen 2008), or horizontal cooperation within the liner shipping sector (Clott et al. 2018) or between seaports (Notteboom et al. 2018), whereas this study explores horizontal coordination between directly competing terminals. Following a qualitative case study approach, the study provides in-depth understanding of all aspects involved in an environment where competing terminals also face pressures to cooperate, including port policy, the institutional environment, terminal behavior, and the linkages between these. Moreover, the authors link these intra-port dynamics to port performance and competitiveness. In doing so, the paper contributes a unique and so far missing perspective to the academic discussion, on a set of issues with an urgent relevance for practice. Deficient coordination between competing terminals impedes the efficient transit of containers in the port area and hence undermines port performance and competitiveness. As these dynamics are the result of ingrained behavioral patterns driven by path-dependent institutional contexts, the resulting problems are persistent. To help address these persistent problems of the sector and the seaport community, this study provides an in-depth understanding of the drivers of these problems, and outlines possible directions for their alleviation.

The paper is structured as follows. Section 2 briefly reviews the literature on intra-port competition and port inter-organizational relations, and outlines the framework uniting the concept of supply chain integration with competition and cooperation in business networks. Section 3 outlines the methodology used. Section 4 introduces the case study of the Port of Rotterdam, illustrates how pressures for competition and cooperation create problems for the port's container handling industry, and identifies the institutional drivers of these coordination problems. Section 5 presents recommendations on how to overcome these problems. Section 6 discusses the findings, their implications for research and practice, and some caveats. Section 7 concludes.

\section{Literature overview and theoretical background}

This section presents a background sketch of the business environment in container ports, the pressures on port actors to engage in various types of interactions, and the theoretical lens through which these issues are addressed in this study. 
The roles of a container terminal

This paper focuses specifically on the container handling sector in seaports. In a typical container supply chain, containers are loaded on a deep-sea container vessel (some with over 20,000 TEU (twenty-foot equivalent unit) capacity) and shipped to some destination (importing) port. Upon arrival, the containers are unloaded at the container terminal contracted by the deep-sea carrier and from there transported to their destinations. Transport to the port's hinterland can take place via inland waterways by barge, over rail by train, or over road by truck. Moreover, some containers are transshipped to smaller destination ports in the hub port's vicinity. For example, containers destined for Scandinavia are often first shipped to larger hub ports in Northern Europe and subsequently transported to Scandinavia by feeder. Of course, in the case of exports, the containers are transported from the hinterland on various modalities to the port and subsequently loaded onto a deep-sea or short-sea vessel.

The processes occurring at an individual deep-sea container terminal are summarized in Fig. 1.

The terminal can be divided into roughly three parts: the quayside (where ships moor), the landside (where containers exit or enter through the terminal gate for or from overland transport), and the stack or yard (where containers are stored temporarily). For simplicity, the stack is omitted from Fig. 1, focusing on container movements in and out of the terminal. The quayside in particular is a bottleneck for container terminals (Carlo et al. 2015): they have a limited length of quayside and a limited number of cranes to service ships. This requires them to balance demands from deep-sea carriers and feeders that fulfill seaside functions, and barges, that predominately fulfill landside functions towards the hinterland or within the port. Another complication is introduced when, in ports with multiple container terminals, the different operators all have to optimize their own landside and seaside processes, while containers also have to be exchanged between different terminals to end up on the designated deep-sea vessel or feeder.

In this context of demands for optimization and trade-offs in the terminal's own operation, and factors that require coordination with other parties, this analysis explores how container terminals relate to one another and other parties in the port.

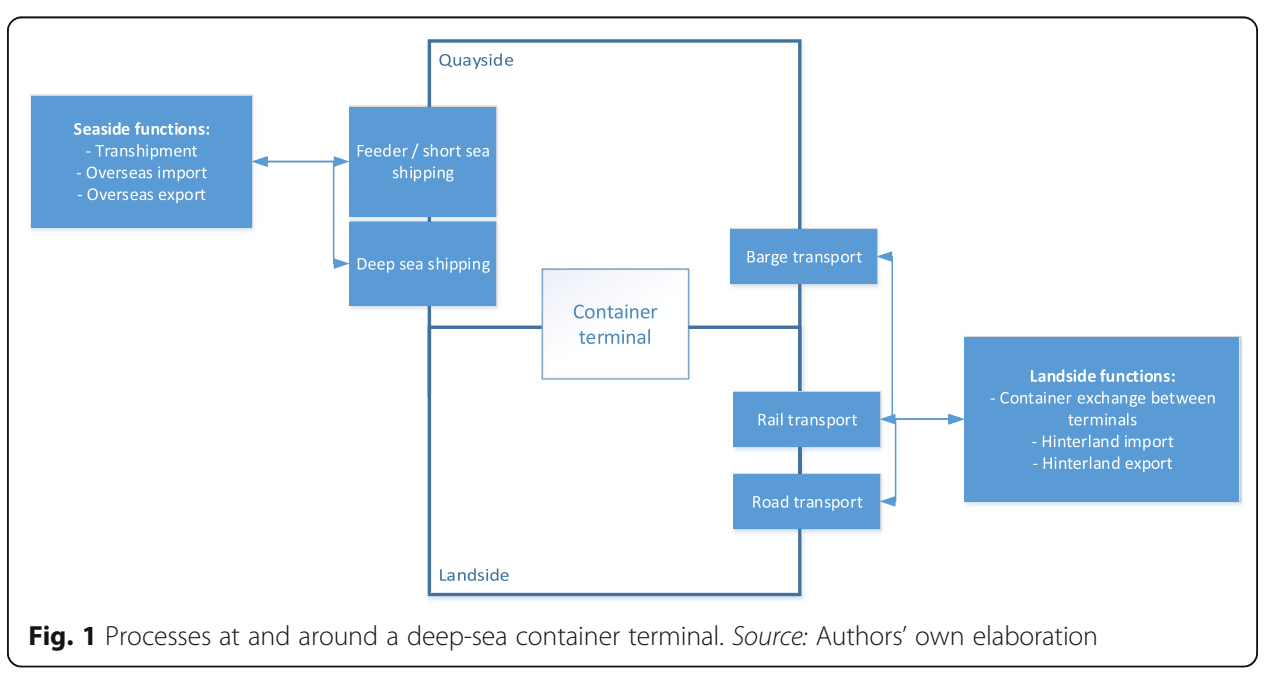




\section{Conflicting pressures}

Container terminals in ports with multiple operators face two conflicting pressures, namely, to a) compete with one another (intra-port competition), but also b) cooperate, as they have a shared interest in the efficiency and competitiveness of the port in which they are operating (relative to other competing ports).

Since the late twentieth century, Port Authorities in Europe have evolved from (municipal) government agencies into more autonomous corporatized entities (Brooks and Cullinane 2006; Borges Vieira et al. 2014). Ports may vary in the degree to which the infrastructure, superstructure, port labor, and other functions are managed by public and/or private actors. The World Bank (2007) specifies a typology of port governance models, ranging from fully public to fully private, and two categories in between. On this spectrum, they recommend the 'landlord' model of port governance: an autonomous Port Authority granting land concessions to port users (in this case competing terminal operators) in exchange for a concession fee and additional stipulations ensuring that the broader societal goals, such as sustainability requirements, of the Port Authority are also met (Notteboom and Verhoeven 2010; De Langen et al. 2012; Debrie et al. 2013). ${ }^{1}$

The pressure for intra-port competition stems from these dominant views on port governance. When the port superstructure, labor, and other functions are left to market actors, it is assumed that competition between port users with similar functions benefits port efficiency and hence competitiveness (De Langen and Pallis 2006; World Bank 2007). Stevedoring activities within a port, including container handling, lend themselves well to natural monopolies, making it prudent for the Port Authority to actively stimulate competition between various operators competing for the same cargo to reduce costs and improve efficiency in the process (De Langen and Pallis 2010). For most Port Authorities, this push for lower costs and higher efficiency is an imperative in an environment in which ports compete for their position in increasingly fluid global supply chains (Robinson 2002).

Juxtaposed to these pressures for competition, competing terminals within a port have significant shared interests and several imperatives for cooperation. First, in the alliance structure of the container shipping sector, carriers share capacity on each other's ships that call at different terminals, and thus containers have to be exchanged between terminals for hinterland, deep-sea, or feeder transport. Secondly, hinterland transport by train or barge may require containers from different terminals to be consolidated on one modality. In addition, because of sustainability concerns and road congestion in port areas, some Port Authorities have already started to demand that terminals transport a larger share of containers to the hinterland by barge and rail, instead of truck (De Langen et al. 2012; Van den Berg and De Langen 2014). Thirdly, as shippers and carriers consider hinterland, short-

\footnotetext{
${ }^{1}$ Another restructuring has taken place in the terminal operating industry in the last decades, whereby the management of container terminals has increasingly become concentrated in a handful of globally operating terminal operating companies (TOCs) (Slack and Frémont 2005). This global management structure and the shifting away of decision making from the local terminal to a global HQ has implications for the position and behavior of individual terminals in ports. However, in attracting clients to their terminal in a given port, the individual terminal has considerable discretion that makes competition between individual terminals at the port level a justifiable focus: different terminals of the same TOC may have different client portfolios, and similarly carriers may call at terminals from competing TOCs (in different ports or even in the same port). For the purpose of this analysis, it is assumed that terminals operating in the same port are exposed to similar institutional pressures that drive the inter-organizational relationships between these terminals.
} 
sea, and deep-sea connectivity and service reliability as major port choice criteria (Martínez Moya and Feo Valero 2017; Parola et al. 2017), it is in the interest of all stakeholders in the port that these processes run smoothly and reliably, or else the port risks losing its position in these supply chains (Castelein et al. 2019). The integration of various processes and activities between actors is an essential underpinning of the efficiency and competitiveness of the port cluster overall (Lavissière and Rodrigue 2017).

\section{The integration imperative}

The terminals' interest in cooperation stems from a need to integrate logistics processes within a port to strengthen the port's efficiency and competitiveness. Supply chain integration is defined as "a firm's objective to attain operational and strategic efficiencies through collaboration among internal functions and with other firms" (Richey et al. 2010, p. 238). In the port context, this concretely entails a "pressure for seamless integration and rapid transit" (Jaffee 2017, p. 732). Considering supply chains as linear constellations, this integration requires the alignment of the transfer of containers from carrier to terminal to hinterland transporters to its destination. However, in more complex supply networks, logistics integration in seaports may also require coordination of container movements between terminals, either in more complex transshipment arrangements or in the consolidation of cargoes from various terminals on one hinterland modality (i.e. barge or train). To some extent, these issues are addressed in existing research on synchromodal transport (Van Riessen et al. 2015), but relational barriers to integration and synchronization have received scant attention in the literature.

This concept of integration - and factors that can enhance or impede it - deserves further attention. Barriers to integration include lack of trust, failure to understand the importance of integration, fear associated with losing control, misaligned goals and objectives, poor information systems, short-term as opposed to long-term focus, and supply chain complexity issues (Moberg et al. 2003). Richey et al. (2010) distill these barriers down to three dimensions: unwillingness to share information, preference for keeping other parties at arm's length, and an internal focus (i.e. on sub-optimizing the firm's own processes to the detriment of processes across firms and the overall performance of a chain or cluster).

Other factors may function as facilitators of integration. These include "interorganizational teams, developing new performance measures, improving communication and information exchange [and] a 'united front' [ ...] to develop a level of commitment among cross-company members of an alliance” (Richey et al. 2010, p. 241). These facilitators work on five dimensions, namely, alignment, communication, structure (risk, rewards, and cost-sharing schemes), quantification (of performance measures), and interdependence.

This brief overview shows that facilitators of integration depend to a great extent on the relations between organizations in the chain, horizontal as well as vertical. Bad relations, evidenced by a lack of trust and an inward-looking focus, impede integration, whereas good relations, evidenced by communication and shared values, facilitate integration. 
The value generated in a supply chain is created through exchanges between organizations. In Allee's (2008) 'value network' (opting for the network rather than the chain metaphor) approach, tangible exchanges include the exchange of goods and money within a network, whereas, more interestingly, intangible exchanges can entail everything from coordination, planning and process knowledge to support, trust, expertise, or affiliation. The key takeaway is that these exchanges create value not only for the recipient, but also for the network overall - an insight that readily applies to terminal operators in a port. However, the extent to which these exchanges arise depends on the strength and quality of the relations between the organizations in the network.

\section{Port inter-organizational relations}

Although the 'landlord' model of port governance is the most common in Europe, local implementations of this model vary between institutional contexts, resulting in considerably different governance structures and positions of Port Authorities (Ng and Pallis 2010; González Laxe et al. 2016). Debrie et al. (2013) argue that port reform constitutes an evolutionary process in which the realized reform is always a compromise between a formal and deliberate reform attempt (i.e. a generic governance model) and bottom-up forces that facilitate, resist, or redirect these reform attempts. These forces are shaped by the local institutional context, the balance of power between public and private stakeholders, the distribution of local decision-making power, and local market conditions.

Port inter-organizational relations between competing terminals are driven by a similar dialectic process. On the formal and deliberate side, Port Authorities and government actors impose formal rules and requirements on terminals, and employ stakeholder management strategies, aiming to stimulate healthy competition that drives costs down and efficiency up, contributing to the performance and competitiveness of the port. Additionally, emergent factors from the local context also influence port inter-organizational relations. Relevant factors for the local stevedoring sector include the institutional environment (how do businesses, and particularly competitors, relate to one another?), local freight market conditions (how much pressure can clients put on terminals and take advantage of the presence of multiple competing operators in a port?), public-private relations (what pathdependent dynamics are there in the relation between port operators and Port Authorities?). Although port policy may prescribe a certain competitive structure, the way port actors relate to one another is determined by these bottom-up factors.

Competitive pressures may impose barriers to logistics integration between competing operators. As discussed above however, other factors can mitigate these barriers and shape a climate that is more conducive to cooperation. Analogous to Richey et al.'s (2010) notion of a united front, Porter and Kramer introduced the term 'shared values' as a force that contributes to the competitiveness of a cluster, such as the container handling sector in a port (Porter and Kramer 2011). This theory attempted to show the way to connect business and society (Vroomans et al. 2017). The concept of shared values resonates with a concept introduced by Fukuyama (1995), namely the "belief system", or the way people associate with one another. If this belief is profound, one can assume that the shared values will be more 
present than when this belief is lacking. Such a shared belief system is necessary to enhance trust between parties in a given system. Geerlings (1997) elaborates on this by stating that a system that might enhance this interaction between people (or actors within a system) could be described as an 'economy of touch': "... the informal contact that influences the management structures and decision making processes” (Geerlings 1997, p. 97) - a crucial concept for the relationships between and within government and the private sector. Lun et al. (2016) explore the concept of social capital in this context: relationships and interactions between stakeholders that allow them to establish linkages, develop synergistic activities, and facilitate collective action. The stronger these inter-organizational ties and relationships are, the better they can be leveraged to enhance performance and generate added value for the port cluster and the region.

\section{Coopetition}

Hall and Jacobs (2010) argue that inter-organizational relations in a port fall somewhere on the spectrum between competitive and collaborative. Too much of one is never good: a too collaborative environment will lose efficiency because it lacks competitive pressure, but too much competition can depress inter-organizational relations to the point that necessary cooperation in certain areas is impeded. In terms of the container handling industry, competition between a port's terminals enhance efficiency, but when competition and rivalry gets in the way of collaboration, this undercuts the port's performance.

This analysis takes a somewhat different perspective and explores how companies may compete and cooperate at the same time, with both types of relations having their own spectrum of intensity, independent of each other. While the tension between competition and cooperation may still be there, it can be alleviated in areas where cooperation is desirable - hence this ostensible tension may be there, but it does not have to be a given obstacle in all interactions. This type of two-faced relationship is called 'coopetition' - a portmanteau of competition and cooperation (Bengtsson and Kock 2000). Song (2003) and Heaver et al. (2001) have explored this concept in relation to inter-port competition and Clott et al. (2018) for the liner shipping industry, but it has particular relevance for the business environment within ports as well. Competition and cooperation are driven by fundamentally different and even conflicting conceptions of how organizations relate to one another, or "logics of interaction" (Bengtsson and Kock 2000), but a context of competitive pressures and mutual dependence may require companies to engage in both. Among container shipping companies, this is done through strategic alliances (Panayides and Wiedmer 2011; Clott et al. 2018), but such global formal cooperation agreements between competitors may not be feasible in the stevedoring industry, as, at port level, operators compete on the basis of local rules, customs, and market conditions.

Sections 2.2 and 2.3 outlined how companies within ports are competitors but also have a shared interest in the port being able to integrate logistics processes effectively. Whether this integration occurs despite competitive pressures depends to a great extent on the quality of inter-organizational relations. More formally, competing terminals within a port would benefit from a coopetitive relation in which 
competitive and collaborative modes of interaction coexist rather than produce friction.

Bengtsson and Kock (2000) outline two conditions for effective coopetition. First they observe that, between firms that manage effectively to cooperate and compete simultaneously, there are "clear norms of the interaction partly based on formal agreement and partly on social contracts" (Bengtsson and Kock 2000, p. 419). Secondly, apart from this tacit understanding, they note that firms in a coopetitive relation formally ensure that competition and cooperation never occur in the same functional areas - e.g. firms compete for customers' business in sales and marketing but cooperate in upstream activities, such as research and development (R\&D) and sourcing. By separating competitive and cooperative logics of interaction across functional areas, there is no ambiguity about the nature of single employees' or departments' interactions with other firms in the sector.

In the case of a container port, terminals can separate competition for carriers' business from cooperation in other aspects. Formally, this can be achieved by separating functions internally, but, more importantly, Bengtsson and Kock (Bengtsson and Kock 2000) emphasize the importance of tacit norms and agreements within and between firms that separate the contradictory logics of cooperation and competition and allow firms to attain the best of both. In the interaction between actors at the intra-port level, this may require attention for community building and the 'soft' elements of port management. These include shared values, trust, a sense of a united front, and a shared vision on future port development.

This conceptual framework is used to address the study's research questions on the basis of a case study on the container handling sector in the Port of Rotterdam. First, how does the tension between pressures for competition and for cooperation manifest itself at the port level? Secondly, what formal and informal factors drive this tension? Thirdly, how can this tension be resolved?

\section{Methodology}

To illustrate how these dynamics can be applied to understand coordination problems in seaports, the situation in the container handling sector in the Port of Rotterdam the largest container port in Europe - is used as an illustrative case study. Apart from publicly accessible information about the port's recent developments, we draw on information from interviews with key stakeholders. Between October 2016 and February 2017, we interviewed three representatives from the container terminal operating industry, three representatives of the Port of Rotterdam authority, two representatives of two major (top 10) container shipping firms, and three representatives of two major freight forwarders (both top 3 global forwarders in terms of sea-freight volume). The freight forwarders were selected as a category of respondents to represent cargo owners (shippers). The majority of shippers tend to be small parties moving small quantities, whereas forwarders deal with demands from the many cargo owners by whom they are contracted and could therefore appropriately voice their perspective. Respondents were selected on the basis of the different categories of stakeholders outlined above: we wanted to speak with several representatives from each major category of port users (shippers, carriers, terminal operators) and the Port Authority. Our criterion for approaching respondents within these organizations was that the respondents had to be 
directly involved in the organization's strategic decision making. Each interview, lasting between 1 and $2 \mathrm{~h}$, was conducted in a semi-structured format on the basis of general discussion questions about the Port of Rotterdam's competitive position and internal dynamics. We also proposed several of our conjectures as formulated in section 2 as discussion points.

We agreed with our respondents beforehand that the conversations would not be recorded, as some of them preferred to make statements in a personal capacity rather than as a formal representative of their company. Extensive notes were taken during the interviews and later transcribed into interview reports - rather than verbatim transcripts. Hence, it should be noted that the statements below are paraphrased rather than quoted literally. In instances where it is not possible to obtain verbatim transcripts, interview notes are generally accepted to be a sufficient alterative (Vogt et al. 2014). During the interviews, two of the authors were present, one in the capacity of interviewer and the other as observer who could ask for clarification when needed.

The analytical approach to the findings from the case interviews is rooted in the exploratory nature of the question, namely how container terminals balance pressures for competition and cooperation and why certain problems arise and persist (see Yin 2009). The section above sketched the important aspects of the case setting (terminal's operating environment and the conflicting pressures they face) and the conceptual categories one should explore when considering supply chain integration and simultaneous cooperation and competition (theory on barriers and facilitators). Drawing on the interview findings, the role and relevance of these concepts for the case can be explored to a great level of qualitative depth and understanding of the mechanisms involved. Using information from different sources serves to highlight complementary aspects of the topic under study, while discrepancies between respondents can be addressed by critically considering their positions and perspectives and juxtaposing these. Ultimately, having identified the main relations and relevant concepts, the recommendations from literature can be tailored to the case context.

To mitigate the potential inaccuracies arising from using written interview notes only, a draft of this paper was presented to our respondents to verify whether their viewpoints were represented accurately - as is good practice in qualitative case study research (Yin 2009). As another validity check, we presented our conclusions to 10 other, 'out-of-sample' experts from Germany, Belgium, and the Netherlands, asking them whether they recognized the findings, and whether any relevant elements were wrong or missing. These validity checks did not raise major issues or omissions. The next section describes our findings.

\section{Case study and findings}

This section describes the case study of the container handling sector in the Port of Rotterdam, identifies coordination problems between terminals, analyzes these in terms of the framework outlined above, and discusses the institutional factors identified by port stakeholders as the main impediments to intra-port cooperation.

\section{Case study background}

The Port of Rotterdam is the largest container port in Europe. It is located along the Hamburg-Le Havre range, which contains four of the 25 largest ports in the 
world, namely Rotterdam, Antwerp, Bremerhaven, and Hamburg. Together these ports handle the lion's share of (Western) Europe's container trade. Recently, the port was extended with the Tweede Maasvlakte project - including the commissioning of three new, fully automated container terminals - to facilitate a projected throughput growth from $11 \mathrm{mln}$ to 33mln TEU per year by 2033.

The container terminals in Rotterdam - particularly those at the new Tweede Maasvlakte - are considered to be state-of-the-art (De Langen et al. 2012). The Port Authority - a corporatized entity owned by the municipality of Rotterdam and the Dutch government - stimulates competition between container terminals in the port to enhance efficiency, and at the moment three global terminal operating companies have one or more deep-sea terminals in the port, besides several smaller operators focusing predominantly on short-sea and barge shipping. In the 1990s, APMT was invited to open a container terminal and compete with the incumbent ECT (now part of Hutchinson Port Holdings), which previously had a monopoly position in the port. When awarding concessions for the newly created land at the Tweede Maasvlakte, ECT and APMT both obtained concessions for additional terminals, and Rotterdam World Gateway, a consortium of DP World and several liner companies, was attracted as a third large competitor within the port (De Langen et al. 2012). The Port Authority maintains a strategy of non-interference and keeps the container terminals at arm's length, emphasizing the importance of free competition within the port (Vroomans et al. 2017).

When the terminals at the Tweede Maasvlakte were commissioned, more capacity became available than was required in a generally depressed freight market. This overcapacity was disadvantageous for all terminal operators, as their new deep-sea quay acquisitions were not operating at full capacity, and their competitive position vis-à-vis their clients is weaker. The relationship between the Port Authority and the terminals, particularly ECT, became strained as a result (Van der Lugt et al. 2014), even culminating in a court case in which ECT accused the Port Authority of irresponsible decisions in creating the new capacity at the Tweede Maasvlakte and demanded indemnification (Mackor 2014).

Integration problems arising from conflicting pressures

Our respondents identified several problems related to deficient cooperation between the competing terminals. For an overview, the separate issues raised by the different categories of stakeholders are listed in Table 1, with their direct consequences for port performance indicated with arrows:

This inventory serves to give a well-rounded view of various coordination problems that may arise between terminals within a port. Of course, if one actor did not mention a certain problem, this does not necessarily mean that he/she does not perceive the problem as relevant. Respondents may also refrain from mentioning a problem in which they have a role. Nevertheless, by eliciting a wide range of stakeholder perspectives and introducing additional validity checks, we aim to paint as complete a picture as possible.

The key takeaway from these statements is that coordination problems between individual terminals have a direct negative impact on key port performance indicators, such 
Table 1 Inventory of problems in inter-terminal coordination (and their effects on performance), as identified by respondents

\begin{tabular}{|c|c|c|c|}
\hline Forwarders & Terminal operators & Port Authority & Carriers \\
\hline $\begin{array}{l}\text { Hold-up of barges } \\
\text { at terminal (deep- } \\
\text { sea lines } \\
\text { get priority) } \\
\rightarrow \text { Containers may } \\
\text { 'miss the boat' }\end{array}$ & $\begin{array}{l}\text { Uncertainty of container } \\
\text { arrival times at other } \\
\text { terminals } \\
\rightarrow \text { Less efficient handling, } \\
\text { longer transit times }\end{array}$ & $\begin{array}{l}\text { Hold-up problems regarding rail } \\
\text { and barge, modal shift towards } \\
\text { these modalities hard to achieve } \\
\rightarrow \text { Large share of truck transport } \\
\text { to hinterland (more congestion } \\
\text { and environmental impact) }\end{array}$ & $\begin{array}{l}\text { Inefficient exchange } \\
\text { of transshipment } \\
\text { containers } \\
\rightarrow \text { Longer transit time, } \\
\text { containers may miss } \\
\text { their boat }\end{array}$ \\
\hline \multirow[t]{2}{*}{$\begin{array}{l}\text { Rail and barge cargoes } \\
\text { are not consolidated } \\
\text { efficiently between } \\
\text { terminals } \\
\rightarrow \text { Longer transit times }\end{array}$} & $\begin{array}{l}\text { Exchange of } \\
\text { transshipment } \\
\text { containers inefficient } \\
\rightarrow \text { Longer transit time, } \\
\text { containers may miss } \\
\text { their boat }\end{array}$ & & $\begin{array}{l}\text { Hinterland rail and } \\
\text { barge connections } \\
\text { inefficient } \\
\rightarrow \text { Longer transit times }\end{array}$ \\
\hline & & & $\begin{array}{l}\text { Congestion at and } \\
\text { between terminals } \\
\text { (unreliable barge } \\
\text { service) } \\
\rightarrow \text { Longer transit times }\end{array}$ \\
\hline
\end{tabular}

Source: Authors' own compilation

as transit time, service reliability, and hinterland connectivity. Our respondents affirm the conjecture that lack of coordination undercuts the competitive position of the port overall. The forwarders we interviewed were most vocal about this issue: for their clients, transit time is a critical decision criterion, as they operate on lean, 'just-in-time' inventory management strategies and have considerable amounts of their cash bound up in merchandise shipments. Too much hold-up and uncertainty in a port will - over time - make shippers consider moving their transport chains through other ports. One forwarder stated that:

Particularly in Rotterdam, inter-terminal container exchange and consolidation of cargo on hinterland modalities has become more problematic [ ... ] The average transit time for a container destined for Germany used to be three days, now it is close to five [ ... T Terminals' own processes and prioritization hurt port performance [in terms of transit time] as well, in that they prioritize the deep-sea calls over inland barge calls, sometimes jeopardizing the timely arrival of our clients' export drops.

Another carrier representative added that "fragmentation of rail and barge cargo across terminals is not dealt with adequately in Rotterdam due to lack of cooperation and information exchange between terminals", causing considerable hold-up. Generally, they note - like the forwarders - that clients may switch to other ports if hold-up problems persist.

Having established the seriousness of the consequences of inter-terminal coordination problems, these problems themselves deserve further scrutiny. From Table 1, these are identified along the lines of 'hold-up', 'inefficiency,' 'uncertainty', and 'unreliability.'

Regarding the locus of these problems, four rough categories of problems can be distinguished:

- Hinterland barge (quayside)

- Hinterland rail (landside)

- Inter-terminal barge and feeder (quayside) 
- Inter-terminal land transport (landside)

Several of Moberg et al.'s (2003) categories of barriers to chain integration can be recognized in the problems sketched.

First, there is the problem of sub-optimization: this is particularly visible regarding barge transport (whether inter-terminal or hinterland transport). At terminals that do not have a dedicated barge quay, barges moor at the same quay as deep-sea lines. However, with the deep-sea carriers being the only paying clients of container terminals, and the risk of high demurrage costs with these calls, the deep-sea lines get priority in quay and equipment allocation - to the detriment of barge servicing. Consequently, the barge service becomes more unreliable, and shippers may find their containers delayed when "their ship [- literally -] has sailed". The container terminal optimizes its quayside resource allocation (i.e. quay space and quay crane capacity) for their paying and demanding container line clients, but as a result the performance of the chain in general suffers.

Secondly, there is the problem of information exchange. Respondents mention 'inefficient' container exchange and hinterland transport connectivity, and 'uncertainty' with regard to arrival times of containers. Even if information that could help increase the efficiency of operations is available to the terminal operator, it is not shared with other parties to the extent that the chain in general benefits from it. The question remains to what extent terminals possess complete and accurate information that could increase efficiency if disseminated.

The third relevant barrier is supply chain complexity. Even if parties are working together efficiently, the complex nature of the supply chain (or chains) could impede chain integration in ports. On a small area and within a limited time window, the container passes from carrier to terminal through customs to a hinterland transport operator, a process that in itself is complex enough to streamline without taking into account synchronization with parallel (and intertwining) activities of other operators. This is not to say that cooperation is doomed to fail, but it should be recognized that perfect efficiency may not be feasible.

Moreover, the terms used to identify the coordination problems are subjective and relative by nature (inefficient and unreliable compared to what?). Therefore, concerning inter-terminal cooperation, the comparisons discussed with our respondents are the major ports nearby: Antwerp, Bremerhaven, and Hamburg. Forwarders in particular find the terminal cooperation in Rotterdam more problematic than elsewhere, even stating that the situation regarding hinterland consolidation and inter-terminal exchange of containers has worsened compared to the past and to other ports. Additionally, a carrier representative stated that "German terminals are better at cooperating and dealing with inter-terminal container exchange," and "rail services to the German hinterland from Antwerp are more reliable." On the other hand, representatives of the Port of Rotterdam Authority noted that, overall, the Belgian and German ports are generally not more efficient than Rotterdam. Moreover, the Port of Rotterdam has a considerable advantage because of the proximity of its deep-sea terminals to the sea.

It could be a matter of perspective whether Rotterdam under- (or over-) performs. However, it is shown that shippers and their agents evaluate a port's performance based on their own experience and adjust their port choice accordingly, so even a 
perception or reputation based on anecdotal evidence can have significant effects in practice. The performance measures that are important to shippers are directly related to the effectiveness of intra-port cooperation. The analysis above suggests that there are several coordination problems that could be addressed, relating to intra-port cooperation and supply chain integration. This in turn depends on the extent to which the inter-organizational relations in the port are conducive to cooperation; this is discussed in the next section.

\section{Institutional drivers of coordination problems}

Having outlined how lacking cooperation undercuts port performance, this section deals with the main impediments to intra-port cooperation. The interviewed stakeholders' perceptions of the drivers behind deficient cooperation are enumerated in Table 2. Particularly regarding the perceived drivers of observable coordination problems, it should be noted that our respondents speak from their own perspective, introducing subjectivity and potential bias into the analysis. We have juxtaposed the perspectives of four different types of port stakeholders to obtain as complete a picture as possible.

Several institutional (formal, informal, and economic) factors can be recognized across the responses:

- Market conditions - notably consolidation and growing market power in the liner sector and overcapacity at the Rotterdam terminals - put pressure on terminals on the demand side to compete on costs

Table $\mathbf{2}$ Inventory of drivers of inter-terminal coordination problems, as identified by respondents

\begin{tabular}{|c|c|c|c|}
\hline Forwarders & Terminal operators & Port Authority & Carriers \\
\hline $\begin{array}{l}\text { Lack of willingness to } \\
\text { collaborate among } \\
\text { container terminals } \\
\text { Port Authority could take a } \\
\text { stronger role in mediating } \\
\text { between terminals }\end{array}$ & $\begin{array}{l}\text { Delays at customs } \\
\text { produce additional } \\
\text { uncertainty }\end{array}$ & $\begin{array}{l}\text { Lack of shared vision ('The } \\
\text { great Rotterdam ideal') }\end{array}$ & $\begin{array}{l}\text { Lack of supply chain } \\
\text { visibility at terminals }\end{array}$ \\
\hline $\begin{array}{l}\text { Often delays at customs } \\
\text { (responsible for checking } \\
\text { and clearing containers at } \\
\text { the terminal) }\end{array}$ & $\begin{array}{l}\text { Port Authority does not } \\
\text { recognize problems } \\
\text { stemming from } \\
\text { competitive focus and } \\
\text { unlevel playing field }\end{array}$ & $\begin{array}{l}\text { Overcapacity gives carriers } \\
\text { leverage over terminals, } \\
\text { 'play out' intra-port } \\
\text { competition to cut costs }\end{array}$ & $\begin{array}{l}\text { Businesslike relations, Port } \\
\text { Authority emphasizes } \\
\text { competition, does little to } \\
\text { enforce cooperation } \\
\text { where needed }\end{array}$ \\
\hline $\begin{array}{l}\text { Consolidation in liner } \\
\text { shipping market puts } \\
\text { pressure on container } \\
\text { terminals } \\
\rightarrow \text { More ad-hoc decision } \\
\text { making } \\
\rightarrow \text { Competition intensifies }\end{array}$ & $\begin{array}{l}\text { Pressure from carriers to } \\
\text { cut costs and increase } \\
\text { service flexibility on the } \\
\text { quayside }\end{array}$ & $\begin{array}{l}\text { Recent port extension has } \\
\text { shaken up the stevedoring } \\
\text { sector. When market } \\
\text { settles again, relations will } \\
\text { return to normal }\end{array}$ & $\begin{array}{l}\text { No performance } \\
\text { agreements between } \\
\text { terminals or between } \\
\text { terminals and hinterland } \\
\text { transporters }\end{array}$ \\
\hline $\begin{array}{l}\text { Initiatives to stimulate } \\
\text { cooperation are not } \\
\text { successful due to the } \\
\text { noncommittal nature of } \\
\text { agreements between } \\
\text { parties and lack of } \\
\text { enforcement }\end{array}$ & & & \\
\hline
\end{tabular}


- Lack of supply chain visibility at terminals, reluctance to share information, uncertainty introduced by customs procedures

- Low levels of trust and cooperative culture: intra-port relations are described as 'arm's length,' 'businesslike,' and lacking a 'shared vision'

- Absence of agreement on key issues and the noncommittal nature and lack of enforcement of existing agreements.

Some differences in perspective can be observed between the various types of stakeholders. Forwarder, terminal operator, and carrier representatives emphasize their wish that the Port Authority would take a stronger stance in enforcing cooperation when necessary, whereas respondents from the Port Authority tend to emphasize market factors as the main driver behind lacking cooperation between terminals. These perspectives are not mutually exclusive, but it is worth noting that there are considerable differences in different actors' perspectives with regard to what is happening and why.

First, all respondents acknowledge the role of market conditions. As the liner shipping business is consolidating through mergers, acquisitions, and alliance agreements the latest reshuffling as of April 2017 has concentrated the major carriers from four into three alliances, representing over $80 \%$ of the global container trade - the market power of carriers relative to terminals increases. This shows particularly on the quayside of terminals. One forwarder indicated that "carrier schedules become increasingly volatile and ships may change terminals or leave while still unloading (so-called 'cut and run' calls) on an ad-hoc basis" and that terminals have to deal with demands for greater service flexibility towards the deep-sea lines. This can produce hold-up problems with customs, and for shippers and forwarders. A Port Authority representative elaborated further on the supply side of the local freight market:

With the Tweede Maasvlakte and developments in the liner market, the terminal market in Rotterdam has been disrupted, and it is still being settled who serves which clients. This has intensified competition, but once the market settles back into equilibrium and terminals are fully operational, relations and cooperation will return to normal.

Secondly, lack of supply chain visibility at the terminal and uncertainty with regard to customs procedures increase uncertainty for other chain actors and increase inefficiency in container transfers. In this case, there is a "one-way flow of process and planning" (Richey et al. 2010, p. 244): the terminal's own constraints determine planning and are not synchronized with the process and planning of other actors. Internally at the terminal, customs procedures and their potential waiting time introduce considerable uncertainty regarding container movements. Also here, a unidirectional relationship exists in which the customs' planning and processes impose constraints on terminals' integration with hinterland transport.

Third, at a more tacit level, there exists what our respondents call "a lack of the 'Great Rotterdam' feeling" (Port Authority) or "pure business," and "arm's length" relations (both carrier representatives). These statements derive from a comparison with other major Northern European ports. As one carrier representative states, "In other 
ports, relations are more informal, less purely businesslike, and ad-hoc agreements are easily made. [ ...] Also the Port Authority adopts a more detached position than elsewhere." Referring to the theoretical background above, this is congruent with a lack of trust and shared vision. In such circumstances, organizational boundaries are too constraining, and organizations are too internally focused to achieve the relational integration that arises with truly cooperative relations. These social norms make inter-organizational relations rather adversarial, negating the potential benefits from a coopetitive relation. Most interviewees emphasize the need to reestablish good contact between stakeholders, but at the same time this is an issue of secondary importance, with sub-optimization of their own processes taking precedence.

Along the formal dimension of the institutional environment, our respondents identify - in various contexts - a lack of formal agreements between parties that have to cooperate in container transfers. These include container terminals and customs, and container terminals and hinterland transporters. More abstract, the lack of formal relations leads to an incongruence in performance measures between these parties, inducing misalignment of incentives. One terminal representative identifies the cause of this as "the interests and business models of terminals and [other stakeholders]" differing considerably and not aligning well in many cases. A carrier representative gave the example that a terminal - having the deep-sea carrier as its most important client - has no direct contractual obligations with barge operators (also discussed by Van der Horst and De Langen (2008)). These conditions are not unique to Rotterdam (e.g. Jaffee 2017) but may be particularly relevant in a context where informal relations between supply chain actors are not conducive to cooperation either.

Having identified and conceptualized the main coordination problems in the Rotterdam stevedoring sector, the next section discusses recommendations to improve supply chain integration and discusses their applicability to the coordination problems outlined.

\section{Implications and recommendations for improvement}

Considering the impact that deficient coordination between neighboring container terminals can have on the performance and competitiveness of seaports, several highly relevant implications can be derived from the study findings for managers in the sector as well as policymakers.

Freight market conditions are considered exogenous for this analysis: no strategy of any of the surveyed port actors will significantly impact on the working of demand and supply in the global freight market. Also, complete resolution of the inherent complexity in container supply chains is likely not feasible. As discussed above, the various interests and business models of all stakeholders involved diverge considerably, so one overarching solution that fully satisfies all stakeholders is unlikely to be feasible. Moreover, we observed evidence of port coordination as a collective action problem. Nearly all actors interviewed proposed solutions in which another party should take the lead (e.g. "terminals should take hinterland transport more seriously," "clearly the Port Authority should take a leading role," "carriers ask too much") but which would be too costly or risky for one actor alone to implement without guaranteed cooperation from the others. Hence, if the institutional context stays the same, none of these proposed improvements would materialize. Considering generic solutions (contracts, agreements, regulations), as well as context-specific implementations of these, we discuss what 
stakeholders might do to improve cooperation and supply chain integration at port level, in spite of a current deadlock situation.

\section{Implications for management}

Lack of visibility and uncertainty can be addressed through improved communication and information exchange. Technically, this can be done using information technology, in the case of seaports for example by extending the functionality of Port Community Systems (Portbase for the Port of Rotterdam) and other platforms (such as Nextlogic and Container Monitor). Similarly, better synchronization of container movements can be achieved through information technology (IT) solutions. This, however, addresses only the 'hardware' side of the problem. For a permanent improvement of chain integration, resources and capabilities are needed, and an informal institutional context conducive to cooperation and integration (the 'orgware'), including trust, commitment, and - most importantly for IT solutions - a willingness to share information. If these are implemented effectively, a positive feedback loop of performance improvement and further integration can result.

On the organizational side, integration can be facilitated through several mechanisms. First, these include incentive alignment and co-performance evaluation among all stakeholders involved. In the case of a port, this could be achieved through more formal arrangements between terminals and parties with whom they do not have a direct contractual relationship. Considering hinterland transportation, a related concept is already being explored by ECT in the Port of Rotterdam, through its European Gateway Service, which arranges hinterland transport under the auspices of the terminal operator. Although this vertically integrated solution is much appreciated by a major carrier interviewed, it may not be feasible to arrange all hinterland transport this way. Horizontally also, coordination may benefit from performance agreements between terminals that impose boundaries on sub-optimization while incentivizing cooperation. It remains a challenge, however, to incentivize terminals to make concessions to the optimization of their own sub-processes, especially if it remains unclear how the costs and benefits of coordination are shared.

Furthermore, several other types of collaborative schemes can be explored. These include inter-organizational teams, risk and reward sharing, collaborative capability building, and more advanced interdependent inter-organizational arrangements (Richey et al. 2010). Referring again to agreements, integration may benefit from performance agreements between terminals that provide mechanisms to share equitably the costs and benefits of integration efforts and hence incentivize cooperation in areas where it matters. Designated inter-organizational collaborative efforts can also facilitate integration. On a deeper level, informal institutions have to change to accommodate these processes by establishing new social norms, greater levels of trust, and a general awareness of shared interests - i.e. a united front. There may be significant barriers to overcome before these changes can be effectuated, including underestimation of the importance or relevance of greater integration, fear of losing control, and key stakeholders' short-term focus.

Bengtsson and Kock (2000) outline how a simultaneously competitive and cooperative relationship can be effectively managed within an organization, providing 
lessons that are relevant for this case study. They argue that competitive and cooperative inter-organizational relations are based on fundamentally different institutional logics. These can coexist within the same firm, as long as they do not overlap across functions, which would cause ambiguity. Container terminals are a typical example of firms that "are forced to interact with each other [in the same sector], giving rise to rivalry and mutual dependence between them" (Bengtsson and Kock 2000, p. 414). Like Richey et al. (2010), Bengtsson and Kock (2000, p. 419) emphasize that the interaction should be governed by "clear norms [ ...] partly based on formal agreement and partly on social contracts [i.e. informal norms and tacit agreement]." Their most relevant propositions relate to the separation of competitive and cooperative logics of interaction within the firm, to be defined by the closeness of an activity to the customer: in downstream activities, competition for customers is warranted, whereas in upstream activities firms can benefit from cooperation. An important condition for this coopetitive relation is that the logic of inter-organizational interaction is not ambiguous within the same functional area. For example, a unit engaging in a cooperative interaction with another firm should not treat its counterpart as a competitor, for if it did, the cooperative effort would not reach its fullest potential. The coexistence of cooperation and competition with direct competitors should be internalized in the organizational culture. This places a responsibility on higher management to refrain from 'tribal' or overly competitive predispositions. Even if it is imperative for business areas not to balance incompatible logics, it is imperative for management to do so effectively. Translating this to the container-handling sector, this means that, even when terminals compete for carriers' business, there can be possibilities for cooperation in areas such as hinterland transport and transshipment.

Despite progress made in these directions, the inherent complexity of terminals' operations may impose a limit on the extent to which integration is possible. This is for an important part driven by the fact that the terminal's quayside is of relevance both competitively (terminals offer quay capacity to their client carriers) and cooperatively (because of barge transport and transshipment). Particularly in relation to these complex resource-allocation problems, performance agreements between terminal operators may serve to balance optimization of terminals' own processes and integration across terminals to some degree.

\section{Implications for policymaking}

Aside from these general recommendations, the case context also justifies some specific recommendations regarding port policy that can be considered by other ports in similar situations. Two particular aspects of port policy are relevant in the case context, namely concession and competition policy and port extension planning.

First, the Port Authority's concession policy in this case imposed two important conditions on the container terminals. By granting concessions to multiple firms and inviting new entrants to compete with incumbents, the Port Authority stimulated competition among the port's terminal operators. Moreover, the additional requirements included in the concession agreements for the Tweede Maasvlakte especially the modal split clause emphasizing hinterland transport by barge and rail 
- put pressure on terminals to cooperate and coordinate with their competitors. It would serve Port Authorities well to consider the tension inherent in these goals and take measures to better reconcile these - for example by attaching performance indicators to various areas in which cooperation is desirable.

Secondly, in the Rotterdam case study, the timing of the port extension was unfortunate: when the new terminals became operational, the freight market was in a depressed state, leading to overcapacity within the port. It was a smart move on the part of the Port Authority not to push to fill all of the newly created land with terminals at once. As a more general recommendation to Port Authorities in the process of extension, it would be wise to consider the possibility of creating overcapacity when the state of the freight market at the time of the completion is less than favorable.

Another, more general suggestion, also made by forwarder, carrier, and terminal operator representatives is for the Port Authority to reconsider its role, and make more use of its position 'above the parties' as a mediator and enforcer (as discussed by for example Van der Lugt 2017). Such 'neutral third party' involvement may guide parties to work towards incentive alignment and stimulate information sharing. At the informal institutional level, the Port Authority as a third party can help bridge differences between stakeholders, facilitate communication, and take the lead in a process of community building. One forwarder in particular emphasized that Port Authorities could do more to enforce cooperation: if agreements are too noncommittal and not enforced, port performance suffers, hurting the interests of both the Port Authority and the port users. This was also emphasized by one of the carriers, who stated that

[in Rotterdam] cooperation and negotiation between container terminals are weak, and there is little pressure for improvement from the Port Authority, which takes on a more detached position. In other ports, relations are more informal, less purely businesslike.

Another forwarder has also seen positive shifts in the last few years: Port Authorities in general, and particularly in Rotterdam, have started to move beyond the 'landlord' role and have become more active in bringing parties together and intermediating. From this perspective, Port Authorities can add value by facilitating, and even enforcing cooperation to smoothen coordination.

\section{Recent developments}

Recently, some initiatives have been undertaken in the Port of Rotterdam to address the problems analyzed in this paper.

To better facilitate the exchange of containers between terminals, the Port Authority has initiated a project to construct a 'container exchange route' (CER) - a dedicated lane that directly connects the main deep-sea terminals in the port (Dijkhuizen 2018). Using this lane, containers can be bundled and exchanged between terminals while avoiding congested public roads. The CER is expected to start operating in 2020. Beyond infrastructure projects such as the CER, several other new developments show the Port Authority in a more active role than expected from a traditional 'landlord' Port Authority. An example of a more leading role in community building is the Global Ports Group, a cooperative arrangement between the Port of Rotterdam Authority and 
four major terminal operating companies (Pieffers 2016). The agreement specifies "information sharing $[\ldots]$ and coordination of joint activities with regard to the efficiency and effectiveness of the container port industry" (quote translated from Pieffers (2016)). Sharing capacity with large call sizes is also said to be being explored. Although this initiative is only a recent phenomenon, some crucial coordination issues can be addressed. First, it signals a commitment to cooperation and an awareness of shared interests. Second, the involvement of the Port Authority as a neutral party may be a way in which commitment and fairness can be enforced. Moreover, a formalized and transparent arrangement with the involvement of a neutral public actor can address competition law implications of cooperation between competitors (Lalkens 2016). Another example is Nextlogic (Nextlogic 2018), a cooperation of numerous market actors, including terminal operators, depots, and barge operators, in which the Port Authority also participates. Nextlogic aims for a central platform to coordinate barge calls across container terminals within the Port of Rotterdam. This initiative combines elements of several of the general solutions discussed above, including technology-based information exchange to reduce uncertainty and inefficiency, and more formal arrangements between horizontally and vertically linked organizations. The market has also offered several digital platform-based solutions, such as TEUbooker and 4shipping, to better align demand and supply of hinterland transportation capacity. However, because they focus on matching shippers and hinterland transporters, these initiatives may do little to address the lack of coordination at terminals.

It should be noted that these developments are still fairly new. In light of the theoretical considerations and the analysis of the issues within the port, these have the potential to address persistent issues, but as of now they are too new and operating at too small a scale to gauge their benefits to the actors involved. It is to be expected that their effectiveness in the long run will depend on actors' trust, commitment, and willingness to share information.

\section{Discussion}

Having discussed at length the implications of the study findings for practice, some remarks are in order regarding the implications for research and the limitations of the study. In line with the three research questions formulated in the introduction, this study set out to understand the implications and drivers of coordination problems stemming from conflicting pressures for competition and cooperation imposed on container terminals and to offer suggestions on how to overcome these. To our knowledge, this study is the first to explore in depth the linkages between the institutional context, inter-organizational relations, behaviour and port performance. In doing so, this study contributes several new insights to existing knowledge, with useful implications for academic research as well as port policy and management. Multiple coordination problems were identified and traced back to institutional barriers to supply chain integration and collaboration. The urgent need to address these issues is illustrated by examples of how these barriers impact port competitiveness in terms of port users' port choices. Regarding the various areas for improvement (as discussed above), a general conclusion is that 'hardware' (resources and capabilities) alone cannot achieve effective chain integration, 
but that integration would require the presence of 'orgware' (institutions) conducive to healthy coopetitive relations with both competitive and cooperative interaction.

For the field of port management research, the study findings highlight the importance of horizontal coordination for port performance. This adds to the observations of Van der Horst and De Langen (2008) - who focused predominantly on vertical coordination - and affirms their conjecture that cooperation seldom arises spontaneously. Particularly in the case of direct competitors, development of formal and informal governance mechanisms is required to adequately balance conflicting pressures. From both the coopetition and the supply chain integration perspective, an important precondition is the creation of a cooperative culture. Formal governance mechanisms alone, prioritizing competition and arm's length transactions, are not enough to resolve the coordination problems stemming from terminals' ambiguous position with regard to one another. Lacking necessary informal institutions, change has to come either from a 'first mover' among the market parties involved or from a non-market third party - the Port Authority. This study also highlights the relevance of insights from the supply chain coordination and coopetition literature to understand and potentially address persistent inter-organizational issues in port clusters. The link between governance, market forces, behavior, inter-organizational relations, and ultimately port performance is still seldomly researched in the academic literature, and this study highlights the relevance of these linkages and their working in the case context under study.

This last point also pertains to one of the study's limitations. This being a case study within a specific port context, the findings might not be directly generalizable to other seaport contexts. The theoretical underpinnings of the findings, i.e. the conceptual categories of barriers and facilitators of integration, however, have proven to be effective in achieving a deep understanding of inter-firm coordination problems. In other cases where these problems arise, these barriers and facilitators may be relevant to differing degrees. But it is important to emphasize that the conceptual framework itself can be adapted to different case contexts. Another important limitation of this study is that unfortunately the approach does not lend itself well for quantification. Therefore it is not possible to compare the relative impact of different issues (which would be useful in prioritizing interventions) or an assessment of costs and benefits of various solutions, but this research can serve as a starting point to develop new approaches. Therefore, future research can be geared towards this analysis of different cooperative schemes, for example using game theory.

\section{Conclusions}

The findings from this study illustrate the complex relation between competitive and cooperative behavior within seaport clusters. Ostensibly, this tension between competition and cooperation requires a balancing act or a single choice of one logic of interaction over the other - as the title of the paper suggests. The study shows that for port performance, it rather matters in which logistics functions lacking cooperation due to competitive pressures leads to problems. In these areas, specific steps can be taken to resolve the tensions inherent to cooperation between competitors. Logistical problems resulting from deficient coordination between competing terminals in a port area are a persistent problem for container ports, and our study findings provide new insights that can help policymakers and managers understand and resolve these issues. As discussed 
above, the findings from this study invite questions for further research in various areas, even beyond the integration of supply chain processes between terminals. In particular, the study raises several considerations for port governance and policymaking. Port authorities' concession and competition policy can be fine-tuned to mitigate holdup due to competitive pressure. Moreover, it can be concluded that the role of a port extension and overcapacity in the case context underlines the need for Port Authorities to consider freight market conditions in their strategic decision-making with regard to port extensions and the granting of new concessions. Earlier research has already identified an evolution of Port Authorities' role beyond the traditional 'landlord' model, including that of a community manager and platform leader (e.g. Hollen et al. 2015). This study provides further suggestions for directions in which Port Authorities may utilize their position to help create value for port users and the port in general. Ultimately, the goal is to function efficiently as a port, but this is underpinned by more tacit factors related to inter-organizational relations that can have a critical influence on the value-creating process in a port. A key step for future research is to more adequately trace and measure these processes, perhaps based on Allee's (2008) 'value network' approach. One key consideration for future work that this study offers is another direction in which to look to broaden the view on how ports create value.

Abbreviations

IT: Information technology; R\&D: Research and development; TEU: Twenty-foot equivalent unit; TOC: Terminal operating company

\section{Acknowledgements}

We would like to thank the editor for considering our manuscript for publication, and two anonymous reviewers for their comments on earlier versions of the paper. Furthermore, we thank our respondents for their time and cooperation in conducting this research, Prof. Em. Henk Moolenaar and Ulco Bottema for their elaborate comments on earlier drafts of this paper, and our external experts for their evaluation of our conclusions.

\section{Authors' contributions}

The authors were involved in all facets of this study and have read and approved the final manuscript.

\section{Funding}

This work is part of the research program EURECA (Effective Use of Reefer Containers Through the Port of Rotterdam A Transition-Oriented Approach) with project number 438-15-505, which is partly financed by the Netherlands Organization for Scientific Research (NWO). No funding organization was involved in the design of the study, the interpretation of data, or the writing of the manuscript.

\section{Availability of data and materials}

The data used and/or analyzed during this study are available from the corresponding author on reasonable request.

\section{Competing interests}

The authors work in a Netherlands Organization for Scientific Research program (EURECA) that is part funded by Seamark, ABB, and Smartport, a joint venture in which the Port of Rotterdam authority is a partner. No funding organization was involved in the design of the study, the interpretation of data, or the writing of the manuscript.

\section{Author details}

1 Department of Public Administration, Erasmus University Rotterdam, Burgemeester Oudlaan 50, 3062PA Rotterdam, The Netherlands. 'Faculty of Policy, Technology, and Management, Delft University of Technology, Jaffalaan 5, 2628BX, Delft, The Netherlands. ${ }^{3}$ Project EURECA (Effective Use of Reefer Containers Through the Port of Rotterdam - a transition oriented approach), Netherlands Organization for Scientific Research (NWO), the Hague, The Netherlands. ${ }^{4}$ Rotterdam University of Applied Sciences, Research Centre Sustainable Port Cities, Heijplaatstraat 23, 3089JB Rotterdam, The Netherlands.

Received: 20 November 2018 Accepted: 22 July 2019

Published online: 06 August 2019

\section{References}

Acciaro M, Ferrari C, Lam JSL et al (2018) Are the innovation processes in seaport terminal operations successful? Marit Policy Manag 45:787-802. https://doi.org/10.1080/03088839.2018.1466062 
Bengtsson M, Kock S (2000) "Coopetition" in business networks - to cooperate and compete simultaneously. Ind Mark Manag 29:422-426

Borges Vieira GB, Kliemann Neto FJ, Goncalves Amaral F (2014) Governanc, Governance Models and Port Performance: A Systematic Review. Transp Rev 34:645-662. https://doi.org/10.1080/01441647.2014.946458

Brooks MR, Cullinane K (2006) Chapter 18. Governance models defined. In: Brooks MR, Cullinane K (eds) Devolution, port governance, and port performance: research in transportation economics 17. Pp 405-435

Carlo HJ, Vis IFA, Roodbergen KJ (2015) Seaside operations in container terminals: literature overview, trends, and research directions. Flex Serv Manuf J 27:224-262

Castelein RB, Geerlings H, Van Duin JHR (2019) Divergent effects of container port choice incentives on users' behavior. Transp Policy. https://doi.org/10.1016/.t.tranpol.2019.04.010

Clott CB, Hartman BC, Cannizzaro R (2018) Standard setting and carrier differentiation at seaports. J Shipp Trade 3. https://doi. org/10.1186/s41072-018-0035-0

De Langen P, Van den Berg R, Willeumier A (2012) A new approach to granting terminal concessions: the case of the Rotterdam world gateway terminal. Marit Policy Manag 29:79-90. https://doi.org/10.1080/03088839.2011.642311

De Langen PW, Pallis AA (2006) Analysis of the benefits of intra-port competition. Int J Transp Econ 33:69-85

De Langen PW, Pallis AA (2010) Entry barriers in seaports. Marit Policy Manag 34:427-440. https://doi.org/10.1080/0308883 0701585134

De Martino M, Carbone V, Morvillo A (2015) Value creation in the port: opening the boundaries to the market. Marit Policy Manag 42:682-698. https://doi.org/10.1080/03088839.2015.1078010

De Martino M, Errichiello L, Marasco A, Morvillo A (2013) Logistics innovation in seaports: an inter-organizational perspective. Res Transp Bus Manag 8:123-133. https://doi.org/10.1016/..rtbm.2013.05.001

Debrie J, Lavaud-Letilleul V, Parola F (2013) Shaping port governance: the territorial trajectories of reform. J Transp Geogr 27: 56-65. https://doi.org/10.1016/j.jtrangeo.2012.07.007

Dijkhuizen B (2018) Aanleg Container Exchange Route in Rotterdamse haven van start. In: Logistiek.nl. https:/www.logistiek.nl/ distributie/nieuws/2018/10/aanleg-container-exchange-route-in-rotterdamse-haven-van-start-101165643. Accessed 17 May 2019

Figueiredo de Oliveira G, Cariou P (2015) The impact of competition on container port (in)efficiency. Transp Res Part A Policy Pract 78

Fukuyama F (1995) Trust: the social virtues and the creation of prosperity. Free Press, New York

Geerlings H (1997) Towards sustainability of technological innovations in transport: the role of government in generating a window of technological opportunity. Vrije Universiteit Amsterdam

González Laxe F, Sánchez RJ, Garcia-Alonso L (2016) The adaptation process in port governance: the case of the Latin countries in South America and Europe. J Shipp Trade 1. https://doi.org/10.1186/s41072-016-0018-y

Haezendonck E (2001) Essays on strategy analysis for seaports. Garant Publishers, Louvain

Hall PV, Jacobs W (2010) Shifting proximities: the maritime ports sector in an era of global supply chains. Reg Stud 44:11031115. https://doi.org/10.1080/00343400903365110

Heaver TD, Meersman H, Van de Voorde E (2001) Co-operation and competition in international container transport: strategies for ports. Marit Policy Manag 28:293-305. https://doi.org/10.1080/03088830110055693

Hollen R, Van den Bosch F, Volberda H (2015) Strategic levers of port authorities for industrial ecosystem development. Marit Econ Logist 17:79-96. https://doi.org/10.1057/mel.2014.28

Jaffee D (2017) Kink in the intermodal supply chain : interorganizational relations in the port economy. https://doi.org/10.1 080/03081060.2016.1204093

Lagoudis IN, Theotokas I, Broumas D (2017) A literature review of port competition research. Int J Shipp Transp Logist 9:. doi: https://doi.org/10.1504/IJSTL.2017.086940.

Lalkens P (2016) Rotterdamse haven wil meer vrijheid van ACM. Het Financ, Dagbl

Lavissière A, Rodrigue J-P (2017) Free ports: towards a network of trade gateways. J Shipp Trade 2. https://doi.org/10.1186/ s41072-017-0026-6

Lun YHV, Carlton J, Bichou K (2016) Examining the economic impact of transport complex economies. J Shipp Trade 1:1-17. https://doi.org/10.1186/s41072-016-0005-3

Mackor R (2014) ECT claimt 1.3 miljard euro van Havenbedrijf. Nieuwsbl. Transp

Martínez Moya J, Feo Valero M (2017) Port choice in container market: a literature review. Transp Rev 37:300-321. https://doi. org/10.1080/01441647.2016.1231233

Moberg CR, Speh TW, Freese TL (2003) SCM: making the vision a reality. Supply Chain Manag Rev 7:34-39

Nextlogic (2018) Van, voor en door de markt. https://www.nextlogic.nl/over-nextlogic/partners/. Accessed 3 Mar 2018

$\mathrm{Ng}$ AKY, Pallis AA (2010) Port governance reforms in diversified institutional frameworks: generic solutions, implementation asymmetries. Environ Plan A 42:2147-2164

Notteboom T, Knatz G, Parola F (2018) Port co-operation: types, drivers and impediments. Res Transp Bus Manag 26:1-4. https://doi.org/10.1016/j.rtbm.2018.04.004

Notteboom T, Lam JSL (2018) The greening of terminal concessions in seaports. Sustain 10. https:/doi.org/10.3390/su10093318

Notteboom T, Verhoeven P (2010) The awarding of seaport terminals to private operators: current practices and viewpoints in European ports. Eur Transp 45:83-101

Panayides PM, Wiedmer R (2011) Strategic alliances in container liner shipping. Res Transp Econ 32:25-38. https://doi.org/10.1 016/j.retrec.2011.06.008

Parola F, Pallis AA, Risitano M, Ferretti M (2018) Marketing strategies of port authorities: a multi-dimensional theorisation. Transp Res Part A Policy Pract 111:199-212. https://doi.org/10.1016/j.tra.2018.03.012

Parola F, Risitano M, Ferretti M, Panetti E (2017) The drivers of port competitiveness: a critical review. Transp Rev 37:116-138. https://doi.org/10.1080/01441647.2016.1231232

Pieffers T (2016) Rotterdam gaat samenwerken met grote terminaloperators. Nieuwsbl, Transp

Pieffers T (2017) Congestie kost bedrijven tonnen extra. Nieuwsbl, Transp

Porter M, Kramer M (2011) Creating shared value. Harv Bus Rev 89:62-77

Richey GR, Roath AS, Whipple JM, Fawcett SE (2010) Exploring a governance theory of supply chain management: barriers and facilitators to integration. J Bus Logist 31:237-256 
Robinson R (2002) Ports as elements in value-driven chain systems: the new paradigm. Marit Policy Manag 29:241-255 https://doi.org/10.1080/03088830210132623

Slack B, Frémont A (2005) Transformation of port terminal operations : from the local to the global. Transp Rev 25:117-130. https://doi.org/10.1080/0144164042000206051

Song DW (2003) Port co-opetition in concept and practice. Marit Policy Manag 30:29-44. https://doi.org/10.1080/0308883032 000051612

Van den Berg R, De Langen PW (2014) Assessing the intermodal value proposition of shipping lines: attitudes of shippers and forwarders. Marit Econ Logist 17:1-20. https://doi.org/10.1057/mel.2014.11

Van der Horst M, De Langen P (2008) Coordination in hinterland transport chains: a major challenge for the seaport community. Marit Econ Logist 10:108-129. https://doi.org/10.1057/palgrave.mel.9100194

Van der Lugt L (2017) Port development company. Role and strategy. In: Geerlings H, Kuipers B, Zuidwijk R (eds) Ports and networks. Strategies, operations and perspectives, Routledge, London and New York, pp 54-67

Van der Lugt LM, Rodrigues SB, Van den Berg R (2014) Co-evolution of the strategic reorientation of port actors: insights from the port of Rotterdam and the port of Barcelona. J Transp Geogr 41:197-209. https://doi.org/10.1016/j.jtrangeo.2 014.09.008

Van Hassel E, Meersman H, Van de Voorde E, Vanelslander T (2016) North - south container port competition in Europe: the effect of changing environmental policy. Res Transp Bus Manag 19:4-18. https://doi.org/10.1016/j.rtbm.2016.03.008

Van Riessen B, Negenborn RR, Dekker R (2015) Synchromodal container transportation. An overview of current topics and research opportunities. In: international conference on computational logistics. Pp 398-421

Verhoeff JM (1981) Seaport competition. Some fundamental and political aspects. Marit Policy Manag 8:49-60

Verhoeven P (2010) A review of port authority functions: towards a renaissance? Marit Policy Manag 38:247-270. https://doi. org/10.1080/03088831003700645

Vogt WP, Vogt ER, Gardner DC, Haeffele LM (2014) Selecting the right analyses for your data. Quantitative, qualitative, and mixed methods. The Guilford press, London, New York

Vroomans J, Geerlings H, Kuipers B (2017) The influence of different political-economic regimes on port clusters in transition. Proceedings of the International Organization of Maritime Economists, Kyoto

Wang K, Zhang A (2018) Climate change, natural disasters and adaptation investments: inter- and intra-port competition and cooperation. Transp Res Part B Methodol 117:158-189. https://doi.org/10.1016/j.trb.2018.08.003

World Bank (2007) World Bank port reform tool kit. World Bank

Yin RK (2009) Case study research: design and methods. Sage Publications

\section{Publisher's Note}

Springer Nature remains neutral with regard to jurisdictional claims in published maps and institutional affiliations.

\section{Submit your manuscript to a SpringerOpen ${ }^{\circ}$ journal and benefit from:}

- Convenient online submission

- Rigorous peer review

- Open access: articles freely available online

High visibility within the field

Retaining the copyright to your article

Submit your next manuscript at $\boldsymbol{\sim}$ springeropen.com 